UDK 621.039(58+75):622.349.5

Ivan P. Drozd, D. S., Senior Researcher, Leading Researcher, Department of Radiobiology and Radioecology

ORCID ID 0000-0002-2965-9082 e-mail: idrozdnbu@ukr.net

Institute for Nuclear Research of the NAS of Ukraine, Kyiv, Ukraine

\title{
TO THE PROBLEM OF RISK MANAGEMENT IN THE FIELD OF THE ATOMIC INDUSTRY OF UKRAINE
}

\begin{abstract}
Summary. The historical retrospective and modern state of the nuclear industry of Ukraine, including the extractive and power generating industries, are analyzed. At this stage, the most important problems are: to define future prospects for the development of the nuclear industry; extension of the term of over-project exploitation of nuclear power units; further decommission the NPP; managing the spent nuclear fuel and radioactive waste.

The peculiarities of introducing a risk-oriented approach at the nuclear industry and energy facilities are discussed: risk assessment and their management.

It is recommended to raise the level of security culture in all branches of the Ukrainian nuclear industry and to recognize the unconditional priority of security over other issues, including those of economic and business nature.

After the collapse of the Soviet Union there were four operating nuclear power plants in Ukraine, as well as the Chernobyl nuclear power plant with its numerous problems. In addition, a number of uranium industry enterprises on the territory of Ukraine and nuclear industry management system and its regulation, requiring significant structural and personnel reform were remained. Despite the economic downturn and political instability in Ukraine, it was succeeded to keep the nuclear energy potential, which is very significant issue in the presence of problems in the fuel and energy complex.

Considering Russia's military aggression against Ukraine the need to replace Russian nuclear fuel reactors with nuclear fuel modifications from other suppliers has been a rose. The replacement will take several years, so to ensure safety during the transition to fuel of a new design will be the main task for nuclear power plants in Ukraine.

At present, about 6000 tons of spent nuclear fuel have been accumulated in Ukraine. Part of the fuel is still being exported to Russia with the purpose of storage and further processing, which in the future has no prospect considering mentioned military aggression.

A large amount of radioactive waste is accumulated in Ukraine. The system of their managing requires an improvement. In particular, the question of the choice of the site for their deep geological disposal is not yet resolved.

Today, Ukraine independently implement sonly the first stage of the nuclear fuel cycle - extraction of uranium ore and the production of uranium concentrate from it, while providing only about $40 \%$ of the needs of Ukrainian NPPs.

The main tasks of risk management in the nuclear industry of Ukraine are as follows:

- adoption of a risk-oriented approach as the basic principle of security;

- improvement of the legislative and methodological base;

- training operation and inspection specialists for atomic industry objects;

- harmonization of the basic principles of a risk-oriented approach with international regulations.
\end{abstract}

(C) I.P. Drozd, 2018 
It is expedient to evaluate and analyze the risks at all nuclear and nuclear energy facilities in Ukraine and, based on this analysis, to develop a perspective vision of industry development.

Keywords: nuclear industry; NPP; risk; risk management; safety culture

\title{
І.П. Дрозд
}

Інститут ядерних досліджень НАН України, м. Київ, Україна

\section{ДО ПРОБЛЕМИ УПРАВЛІННЯ РИЗИКОМ В ГАЛУЗЯХ АТОМНОЇ ІНДУСТРІї УКРАЇНИ}

\begin{abstract}
Анотація. Проаналізовано історичну ретроспективу та сучасний стан атомної індустрії Украӥни, включаючи видобувну й енергогенеруючу галузі. На даному етапі найважливішими проблемами є: визначитись з подальшими перспективами розвитку атомної індустрії; подовження термінів понадпроектної експлуатачії атомних енергоблоків; подальше виведення АЕС 3 експлуатації; поводження 3 відпрацьованим ядерним паливом $i$ радіоактивними відходами.

Обговорюються особливості впровадження ризик-орієнтованого підходу на об'єктах атомної промисловості та енергетики: оцінювання ризиків й управління ними.

Рекомендується в усіх галузях атомної індустрії Украӥни підвищувати рівень культури безпеки та визнавати безумовний пріоритет безпеки над іншими питаннями, у т.ч. економічного та бізнесового характеру.
\end{abstract}

Ключові слова: атомна індустрія; АЕС; ризик; управління ризиком; культура безпеки

\section{Стан атомної індустрії України}

Експертний аналіз стану атомної індустрії в Україні детально проведено в [1]. Після розпаду Радянського Союзу в Україні залишились чотири діючі атомні станції із п’ятнадцятьма реакторами, а також Чорнобильська AEC iз іiі численними проблемами. До того ж на території України залишилося декілька підприємств уранової промисловості і система управління атомною галуззю та iii регулювання, що потребувала суттєвого структурного та кадрового реформування. Процеси реформування відбувалися на тлі економічного занепаду та політичної нестабільності. Незважаючи на це, в Україні вдалось зберегти атомний енергетичний потенціал, що є дуже суттєвим за наявності проблем у паливно-енергетичному комплексі, які особливо загострилися після політичних подій 2014 року.

Цілком очевидно, що в нинішній ситуації в Україні необхідно зберегти атомний енергетичний потенціал принаймні на декілька найближчих десятиліть. Для цього уряду, бізнесу та громадськості потрібно буде вирішити декілька важливих першочергових питань, щоб вони найближчим часом не перетворилися на проблеми. 


\section{Питання гарантування безпеки діючих АЕC}

В історії розвитку атомної енергетики України, за статистичними даними щодо приросту енергогенеруючих потужностей, можна виділити три базові періоди [1].

1. 1977-1991 pp. - дуже швидкий приріст потужностей АЕС - у середньому близько $9 \%$ за рік.

2. 1992-2010 pр. - період практичного призупинення введення нових потужностей і повного зупинення роботи всіх блоків Чорнобильської АЕС.

3. 2011-2017 pp. - період перевірки стану блоків АЕС, що відпрацювали проектний термін експлуатації, та продовження їх роботи понад проектний термін на 10-15 років; підготовчі роботи до зняття блоків АЕС з експлуатації.

На сьогодні на українських АЕС працюють 15 ядерних енергоблоків із сумарною потужністю 13835 МВт (табл. 1).

Таблиця 1 - Генерування електроенергії на атомних електростанціях України

\begin{tabular}{|c|c|c|c|}
\hline \multicolumn{4}{|c|}{ АЕС України } \\
\hline Назва AEC & $\begin{array}{l}\text { Кількість та тип } \\
\text { енергоблоків }\end{array}$ & $\begin{array}{c}\text { Загальна } \\
\text { потужність, } \\
\text { МВт }\end{array}$ & Особливі відмітки \\
\hline ЧАЕС & 4 РВПК-1000 & 4000 & $\begin{array}{l}\text { Знаходиться на стадії зняття } 3 \\
\text { експлуатації. }\end{array}$ \\
\hline ПУАЕС & 3 BBEP-1000 & 3000 & $\begin{array}{l}\text { На 2, 3-му блоках } \\
\text { використовують паливо } \\
\text { Westinghouse. }\end{array}$ \\
\hline 3AEC & 6 BBEP-1000 & 6000 & $\begin{array}{l}\text { Наявність ССВЯП. } \\
\text { У 1, 3, 4, 5-й блоки завантажено } \\
\text { паливо Westinghouse. } \\
\text { Пожежа в кабельній шахті } \\
\text { у } 1984 \text { р. }\end{array}$ \\
\hline PAEC & $\begin{array}{l}2 \text { BBEP-440 } \\
2 \text { BBEP-1000 }\end{array}$ & 2835 & $\begin{array}{l}\text { Карстові процеси. } \\
\text { Підготовка до завантаження } \\
\text { палива Westinghouse у 3-й блок. }\end{array}$ \\
\hline XAEC & 2 BBEP-1000 & 2000 & $\begin{array}{l}\text { Викид радіоактивної пари в } \\
\text { гермоприміщення. Загинула } 1 \\
\text { людина (1996). }\end{array}$ \\
\hline
\end{tabular}

У сумарній структурі потужності електричної генерації України АЕС займають лише 25\%. Проте останніми роками вони виробляють до 55\% усієї електричної енергії країни.

На сьогодні сім із п'ятнадцяти реакторних блоків, що перебувають в експлуатації, мають подовжений термін експлуатації [2]. Інші досягнуть їхнього рівня в найближчі три - п'ять років. Незважаючи на те, що подовження терміну експлуатації атомних блоків є міжнародною практикою, є підстави вважати, що вони є менш надійними, ніж нові. Крім цього, подовжені терміни експлуатації теж скоро закінчаться.

Зважаючи на військову агресію Російської Федерації проти України, варто 3 розумінням ставитись до заміни в реакторах ядерного палива російського 
дизайну на модифікацію ядерного палива інших постачальників, наприклад компанії Westinghouse [1]. Перехід до палива компанії Westinghouse триватиме декілька років, тому, попри всі внутрішні та зовнішні обставини, для атомних станцій України головним завданням буде гарантування безпеки при переході до палива нового дизайну.

Виведення з експлуатації атомних блоків - це складний і дорогий процес. Згідно з оцінками економістів, витрати при цьому становлять близько 60\% капітальних витрат на будівництво.

Стосовно АЕС, які мають бути виведені з експлуатації до 2055 р., очевидно слід зосередитися на заснуванні спеціального фонду, розробці концепції, програм і технології виведення з експлуатації з урахуванням досвіду країн, у яких цей процес уже втілюється в життя [1]. У вирішенні перерахованих завдань важливу роль відіграє міжнародна співпраця, яка має зміцнюватись для гарантування цілковитої безпеки.

\section{Питання поводження 3 відпрацьованим ядерним паливом $[1,3]$}

На цей час в Україні накопичено близько 6000 тонн відпрацьованого ядерного палива (ВЯП), більша частина якого зберігається у сховищах «вологого типу», за винятком 1350 тонн, що перебувають у сховищі «сухого типу» Запорізької AEC. Наразі частина палива з реакторів українських АЕC досі вивозиться 3 метою зберігання та подальшої обробки до Російської Федерації. Однак енергетична стратегія України відносно поводження 3 ВЯП передбачає реалізацію так званого «відкладеного рішення», згідно з яким ВЯП тривалий час (50 і більше років) зберігатиметься у власних сховищах із подальшим визначенням майбутніх перспектив. Для цього слід буде втілити в життя проект спорудження централізованого сховища ВЯП у Чорнобильській зоні відчуження, обговорення якого відбувається вже тривалий час. Для України вирішення питання поводження з ВЯП - це насамперед вирішення питання фінансових ресурсів. Безсумнівно, без міжнародної допомоги розв'язати це питання буде надто складно.

\section{Питання поводження 3 радіоактивними відходами $[1,3]$}

Україна посідає друге місце в Свропі за кількістю накопичених радіоактивних відходів (РАВ) різного рівня. Система поводження з РАВ вимагає розвитку та вдосконалення. Зокрема, наразі не вирішено питання про вибір майданчика для глибинного геологічного захоронення високоактивних РАВ із тривалим терміном потенційної небезпеки. Це одне з найважливіших питань, оскільки вже у 2018 році Україна має почати забирати високоактивні відходи 3 ВО «Маяк» (Російська Федерація), що утворилися в результаті перероблення відпрацьованого палива з реакторів ВВЕР-440 Рівненської АЕС. Це питання не лише безпеки, але й економіки, адже порушення умов угод може призвести до застосування штрафних санкцій.

\section{Родовища урану в Україні $[1,4]$}

Українські поклади урану сконцентровані в Дніпропетровській i Кіровоградській областях. 31945 р. і донині уран видобували на 11 родовищах, 
які сьогодні мають різний статус. Чотири найстаріших (Первомайське, Жовторіченське, Девладово та Братське) вичерпалися у 1950-1990-х роках; ще три (Сафонівське, Северинівське та Квітневе) або законсервовані, або не розробляються через брак коштів. Активно нині розробляються Мічурінське, Ватутінське, Центральне та Новокостянтинівське уранові родовища поблизу Кропивницького.

Нині переробку й первинне збагачення уранової руди здійснює ДП «СхідГЗК» - єдине в Україні підприємство, що забезпечує видобуток природного урану i виробництво його оксидного концентрату. Воно підпорядковане Міністерству енергетики та вугільної промисловості України.

Як відомо, ядерний паливний цикл (ЯПЦ) в Україні $є$ неповним, і у зв'язку 3 цим значною мірою розвиток ядерної енергетики в наявному форматі його функціонування залежить від Росії (рис. 1) [5]. У цей час самостійно Україна реалізує лише першу стадію ЯПЦ - видобуток уранової руди та виробництво 3 неї уранового концентрату, забезпечуючи при цьому лише близько 40\% від потреби українських АЕС - близько 1000 тонн уранового концентрату 3 необхідних 2,5 тис. тонн. Увесь виготовлений в Україні урановий концентрат до останнього часу перероблявся в Росії.

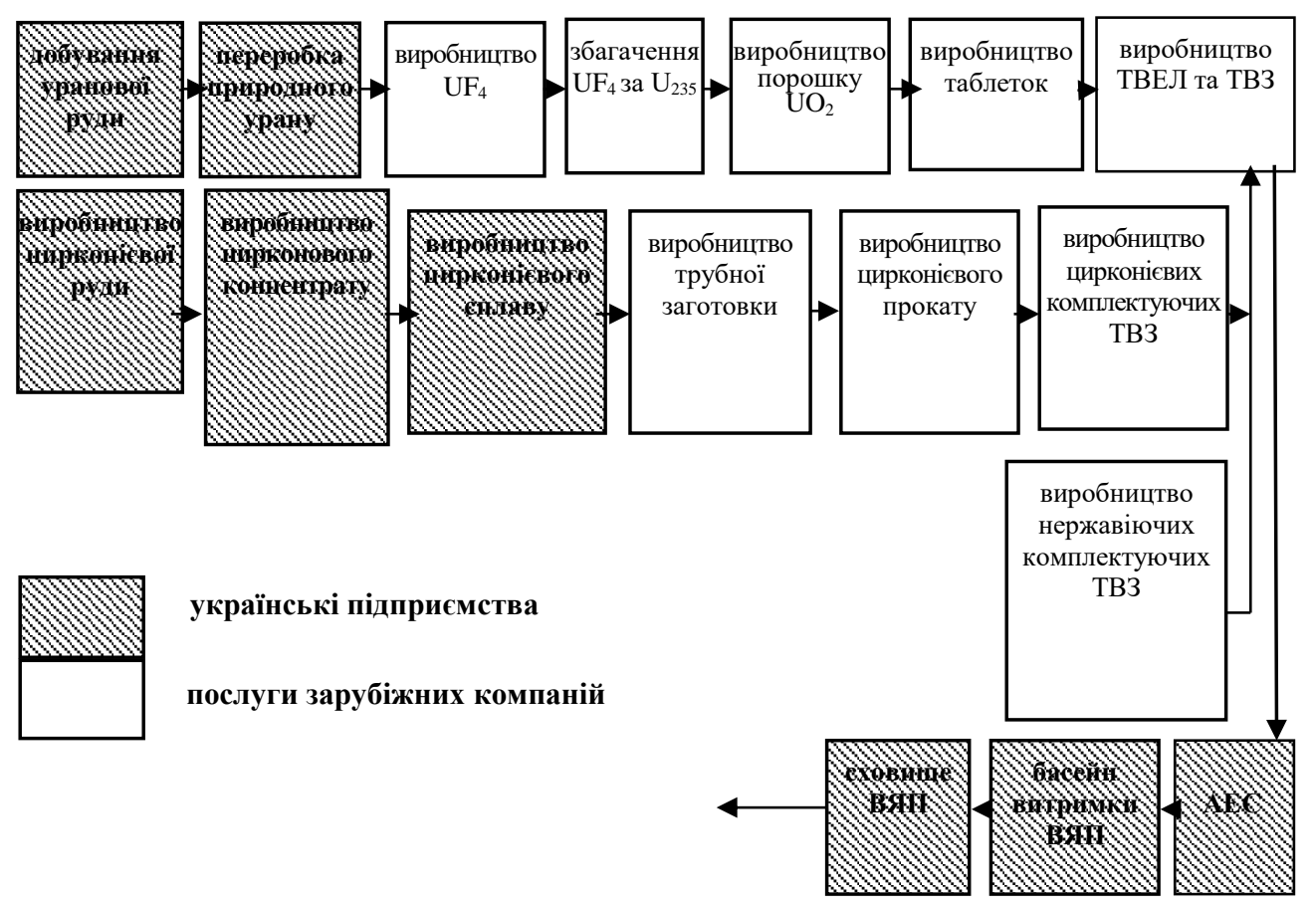

Рис. 1 - Структура ядерно-паливного циклу України

\section{Ризики в атомній промисловості [5]}

Багато навчальних посібників, стандарти та навіть Закон України "Про об'єкти підвищеної небезпеки" [6] ототожнюють ризик з імовірністю небажаної події. 
Так, у законі наведені такі визначення:

- "ризик - ступінь імовірності визначеної негативної події, що може відбутися у визначений час при визначених обставинах на території об'єкта підвищеної небезпеки чи за його межами;

- управління ризиком - процес прийняття рішень та здійснення заходів, спрямованих на забезпечення мінімально можливого ризику."

Викладене дає підстави для висновку про помилкове визначення поняття ризику у вітчизняній практиці.

Ризик необхідно визначати як добуток імовірності небажаної подї̈ на збиток, щуо вона може принести.

Концепція прийнятого ризику містить дві складові, а саме оцінку ризику та керування ризиком.

Оцінка ризику - це аналіз виникнення і масштабів ризику в конкретній ситуації. Головне призначення ii - це визначення пріоритетів серед спектру негативних впливів і в пов'язаному з цим порівнянні застосованих заходів. Оцінка ризику запроваджується, щоб визначити причини існуючих проблем.

Процес розробки рішення про те, як усунути причини відповідних небезпек, є керування ризиком.

У міжнародній практиці поширеним підходом до управління ризиками є так звана «П'ятикрокова система» [7-9].

Крок 1. Ідентифікація небезпек, що призводять до ризику. На цьому етапі потрібно розглянути на робочому місці все, що потенційно може спричинити заподіяння шкоди, i визначити працівників, які можуть зазнати небезпеки.

Крок 2. Оцінювання та "ранжирування" ризиків (їх серйозність, імовірність, розподіл за важливістю).

Крок 3. Визначення превентивних заходів. На цьому етапі необхідно ідентифікувати підходящі заходи для виключення ризиків та управління ними.

Крок 4. Вжсивання заходів. Реалізація цього кроку полягає у складанні плану реалізації захисних та превентивних заходів, визначенні, хто, що і коли конкретно робить і якими засобами забезпечується виконання запланованих заходів.

Крок 5. Моніторинг та перевірка. Оцінку слід проводити на регулярній основі. Результати оцінки повинні переглядатися при значущих змінах в організації виробництва, а також при нещасних випадках.

\section{Оцінка ризику в атомній енергетиці [5]}

Як будь-який інший великий промисловий комплекс, АЕС є джерелом ризику для навколишнього середовища. Ризик цей пов'язаний в основному 3 виробництвом, утриманням і збереженням радіоактивних речовин. Для того щоб ризик був прийнятним, впроваджуються різні заходи на всіх етапах життєвого циклу АЕС, починаючи з розробки і закінчуючи ऑiі демонтажем та утилізацією радіоактивних відходів.

Мірою ризику в суспільстві при значенні ризику рівному одиниці є ціна життя людини. Так події, у результаті яких один нещасний випадок із смертельним результатом відбувається на один мільйон людей, звичайно не помічаються в суспільстві (імовірність виникнення $\mathrm{P}=10^{-6}$ ), а події, які мають частоту летального результату $\mathrm{P}>10^{-6}$ розцінюються як нещасні випадки. 
Законодавство багатьох країн, їх нормативно-правова база щодо експлуатації атомних станцій встановлюють допустимі значення частот подій 3 летальним результатом у межах $1 \cdot 10^{-5}-1 \cdot 10^{-6}$ подій у рік на один реактор. Відповідно до норм радіаційної безпеки України при визначенні величини ризику оперують такими поняттями, як прийнятний ризик і верхня межа індивідуального ризику. Рівень прийнятного ризику для персоналу приймається на рівні $1 \cdot 10^{-4}$ за рік, а для населення $-1 \cdot 10^{-5}$ за рік, верхня межа індивідуального ризику для опромінення осіб з персоналу приймається на рівні $1 \cdot 10^{-3}$ за рік, а для населення $-5 \cdot 10^{-5}$ за рік.

Економічний збиток законодавством не нормується.

Як правило, якісна і кількісна оцінка ризиків виконуються за допомогою готових комп'ютерних програм - так званих імовірнісних кодів, що розроблені для проведення імовірнісного аналізу безпеки (ІАБ) [5]. Найбільш розповсюдженими 3 них $є$ коди з використанням моделей дерев подій і дерев відмов, зокрема IККА8.

Перший розрахунок, який виконується - це розрахунок частоти ушкодження активної зони реакторної установки, або ІАБ 1 рівня.

Крім ІАБ-1, до імовірнісних аналізів безпеки АЕС можуть входити розрахунки інших рівнів:

IАБ- 2 ,

ІАБ-3,

а також "Living PSA" - "живий ІАБ".

ІАБ-2 - визначає кількість продуктів радіоактивного розпаду, що викидаються, при ушкодженні чи руйнуванні активної зони ядерної установки, ізотопний склад продуктів розпаду і оцінку імовірностей частот таких подій, тобто ІАБ-2 розглядає запроектні аварії.

ІАБ-3 містить аналіз розповсюдження радіоактивних речовин при запроектній аварії у залежності від метеорологічних, кліматичних, гідрографічних і інших умов протікання запроектної аварії. Результати ІАБ-3 використовуються для розробки плану заходів щодо захисту населення при важких аваріях.

"Living PSA" - "живий ІАБ" - періодично поновлюваний імовірнісний аналіз безпеки АЕС. У розрахунках враховуються всі зміни, що проведені на реакторі під час ремонтів і технічного обслуговування. Використовується для оцінки ефективності проведених заходів щодо безпеки.

Очевидно, що для таких розрахунків повинні бути заготовлені заздалегідь усі вихідні дані і математичні імовірнісні моделі розв'язуваних задач.

Кожна АЕС по чинному законодавству, як і будь-який потенційно небезпечний об'єкт, зобов'язана періодично надавати звіти про безпеку, де має бути доведено, що ризик великої аварії з руйнуванням реакторної установки не перевищує допустимих значень. На практиці безпека АЕС оцінюється імовірністю ушкодження реакторної установки при різних небезпечних зовнішніх і внутрішніх впливах, таких як падіння літака на РУ, землетрус, неспрацьовування захистів, втрата управління через знеструмлення, пожежі, течі тощо. Звичайно розглядають до 50 небезпечних чинників на різних режимах роботи реактора. Розрахунки імовірнісного аналізу безпеки проведені для АЕС в усьому світі, у тому числі і для АЕС України.

Найкращі показники безпеки виявились на АEC Японії, хоча це не убезпечило їх від запроектної аварії на АЕС Фукусіма Даїчі в 2011 році. 
За показником небезпечних аварій українські АЕС особливо не виділяються серед АЕС інших країн світу [5]. Зазначимо, що концептуальні відмінності на наших AЕC все-таки існують. Це, у першу чергу, малий порівняно із західними установками рівень автоматизації i, внаслідок цього, велике значення "людського чинника" для безпеки. Розрахунки імовірностей зобов'язані враховувати імовірність помилки людини-оператора. Оскільки усталених вітчизняних методик урахування можливих помилок оператора не існує, розрахунки проводяться за методикою США, з використанням їхніх баз даних, що призводить до деякого завищення результатів. Однак це можна вважати допустимим, оскільки наші оператори, за оцінками західних фахівців, мають кращу підготовку.

У світовій практиці при управлінні ризиком, прийнято користатися принципом ALARA: "Будь-який ризик повинен бути знижений настільки, наскільки це розумно досяжне".

\section{Проблеми і задачі впровадження ризик оріснтованого підходу в атомній галузі України}

В Україні існує ряд законодавчих актів, що регулюють безпеку населення i територій, покликаних забезпечити гарантований рівень безпеки громадянина і суспільства $[6,10-13]$. Законодавчі акти передбачають упровадження ризик орієнтованого підходу (РОП), але поки що цих змін недостатньо.

Державної програми забезпечення безпеки на основі РОП в Україні до цих пір не існує, у підсумку на забезпечення безпеки та ліквідацію наслідків аварій витрачаються значні кошти.

Основні задачі упровадження РОП сформульовані в постанові Кабінету Міністрів України від 7 лютого 2001 р. №122 [12] і $є$ такими:

- Розробка та впровадження науково-практичних методів та рекомендацій щодо переходу на систему аналізу та управління ризиками як основу регулювання безпеки населення та територій.

- Підготовка методик ідентифікації та оцінки ризиків від джерел надзвичайних ситуацій.

- Проведення фундаментальних та прикладних наукових досліджень 3 оцінки ризику та прогнозування виникнення надзвичайних ситуацій.

Однак, цей документ виконано не повністю. Тому основні задачі впровадження РОП в Україні на цей час є такими:

$>$ прийняття РОП основним державним принципом забезпечення безпеки;

$>$ збір та аналіз даних про НС із позицій РОП;

$>$ проведення освітянської роботи, з метою зміни ставлення фахівців до основних принципів РОП;

розробка національної програми регулювання безпеки на основі РОП, що включає:

- удосконалення законодавчої та методичної бази;

- навчання фахівців з експлуатації та інспекції ПНО;

- узгодження основних принципів РОП з міжнародними нормами;

- повсюдне вивчення принципів РОП у вищій школі. 


\section{Класифікація ризиків}

У зв'язку з наявністю в літературі різних визначень та трактувань ризику та пов'язаних 3 ним понять, розглянемо можливу класифікацію ризиків (рис. 2) [5].

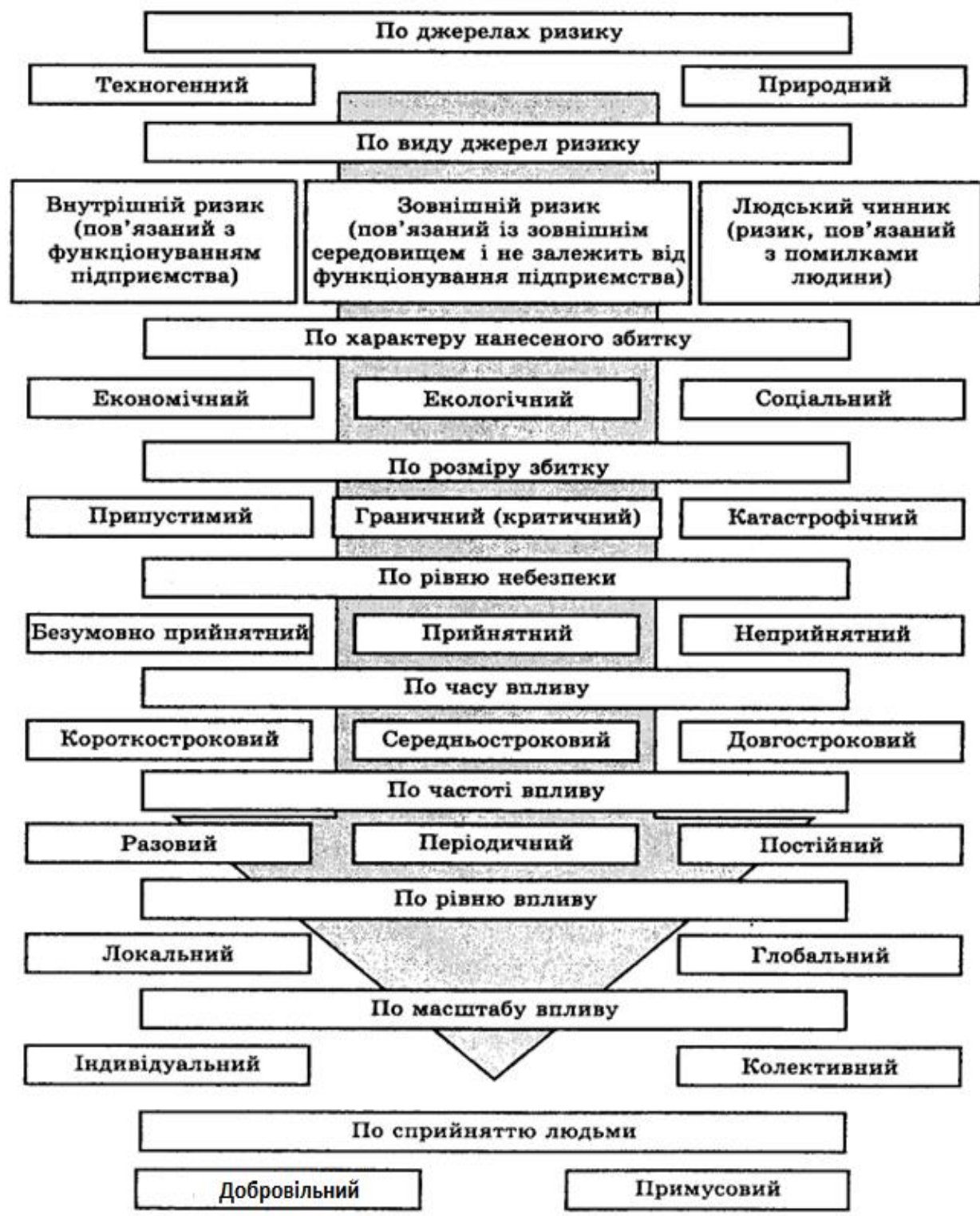

Рис. 2 - Схема класифікації ризиків

Ретельно проаналізувавши усі напрямки атомної і ядерно-енергетичної галузей України, ми дійшли висновку, що, залежно від напрямку, оцінку ризику доцільно проводити за різними методами (табл. 2). 
Таблиця 2 - Рекомендовані методи оцінки ризику для різних напрямків атомної і ядерно-енергетичної галузей України

\begin{tabular}{|c|c|c|c|c|}
\hline \multicolumn{5}{|c|}{ Напрямок галузі } \\
\hline $\begin{array}{c}\text { Видобуток } \\
\text { урану }\end{array}$ & $\begin{array}{c}\text { Виготовлення } \\
\text { концентрату }\end{array}$ & $\begin{array}{c}\text { Виготовлення } \\
\text { ТВЕЛів }\end{array}$ & $\begin{array}{c}\text { Генерування } \\
\text { електроенергії }\end{array}$ & $\begin{array}{c}\text { Поводження з } \\
\text { відходами }\end{array}$ \\
\hline HRA & HRA & HRA & HRA & HRA \\
\hline SWIFT & OTP & RSM & AПH & PHA \\
\hline ALARP & SWIFT & & ALARP & HAZOP \\
\hline OTP & & & M-K & \\
\hline
\end{tabular}

*пояснення до табл. 2

HRA (Human Reability Assessment) - аналіз впливу людського фактора;

PHA (Premliminary Hazard Analysis) - попередній аналіз небезпек;

SWIFT (Structured what if techniques) - структурований аналіз сценаріїв методом "що, якщио";

RSM (Reliability-Centered Maintenance) - технічне обслуговування, спрямоване на забезпечення надійності;

ALARP (As Low As Reasonably Practicable) - аналіз ефективності витрат - аналіз "витрати - вигода";

ОТР - очінка токсикологічного ризику;

АПН - аналіз причин і наслідків - об'єднує в собі аналіз дерева несправностей і аналіз дерева подій;

М-К - моделювання методом Монте-Карло;

HAZOP (Hazard and Operability Study) - дослідження небезпеки і працездатності.

Легко помітити, що для всіх напрямів атомної і ядерно-енергетичної галузі для оцінки ризику рекомендується застосовувати HRA-метод (аналіз впливу людського фактора), і це не випадково. Аналіз аварій і катастроф в Україні показує, що людський фактор в усіх випадках відігравав далеко не останню роль. Зауважимо, що це є характерним не лише для України, але й для інших пострадянських республік, де відбувались великі техногенні аварії. В країнах Заходу вплив цього фактора $є$ менш відчутним, що очевидно пов'язано 3 вищим рівнем культури безпеки на потенційно небезпечних виробництвах. Тому можна рекомендувати ширше впроваджувати культуру безпеки на атомних об'єктах України.

В Україні згідно з Концепцією управління ризиками виникнення надзвичайних ситуацій техногенного та природного характеру [12] за рекомендовані рівні прийнятних ризиків рекомендовано вважати:

$>$ мінімальний ризик - такий що є менший або дорівнює $1 \cdot 10^{-8}$;

$>$ гранично допустимий ризик - такий що є менший або дорівнює $1 \cdot 10^{-5}$.

Очевидно, що за наявного стану безпеки в атомній галузі досягнення вказаних рівнів прийнятних ризиків $є$ неможливим. На цей випадок в Концепції зауважено, що рекомендовані рівні досягаються в 2 етапи, залежно від умов, що склалися в галузі.

Там же зазначено, що одним із ефективних механізмів державного регулювання управління ризиками є нагляд і контроль. Тут доречно згадати про дієвий метод контролю, притаманний атомній галузі, а саме: застосування на об'єктах галузі контрольних рівнів, які дозволяють ефективно знижувати дози опромінення на виробництві, а значить, і ризики. Виходячи 3 цього, 
рекомендуємо 3 метою досягнення рамкових значень прийнятних ризиків широко застосовувати контрольні рівні на виробництві.

Доцільно оцінити і проаналізувати ризики на усіх об'єктах атомної і ядерноенергетичної галузей України i на підставі цього аналізу розробити перспективне бачення розвитку галузей.

\section{Кроки для поліпшення становища в ядерній енергетиці України $[1,13,14]$}

- 3 метою послаблення залежності від Росії 30 грудня 2014 р. Україна підписала контракт з компанією Westinghouse Electric Company на поставку ядерного палива, що поклало початок диверсифікації джерел постачання ядерного палива і тим самим стало кроком до зниження ризиків повної залежності від російського монополіста. (Крім Південно-Української АЕС, до кінця 2017 р. після модернізації систем внутрішнього реакторного контролю паливо компанії Westinghouse планувалося завантажити в активні зони енергоблоків №o 1, 4 Запорізької АЕС).

- Планується поступове збільшення потужності діючих реакторів типу ВВЕР-1000 до рівня 110\% номінального за рахунок модернізації реакторних турбін.

- Укладено контракт 3 компанією URENCO на постачання збагаченого урану, який використовуватиметься для виробництва ядерного палива для AEC України на підприємстві компанії Westinghouse у Швеції.

- Укладено Угоду з південнокорейською компанією Korea Hydro \& Nuclear, що передбачає співробітництво 3 питань добудови енергоблоків №№ 3, 4 Хмельницької АЕС та реалізації проекту «Енергетичний міст Україна - СС».

- Укладена угода 3 компанією Holtec International та досягнуто згоди Комісії 3 ядерного регулювання США щодо інвестування коштів у будівництво Централізованого сховища відпрацьованого ядерного палива (ЦСВЯП), вартість якого зросла до 1,4 млрд доларів, тому воно не може бути побудоване виключно за бюджетні кошти України.

\section{Висновки}

За наявних реалій і в близькій перспективі атомна енергетика України залишатиметься практично основним джерелом електроенергії. Водночас майже всі атомні станції наближатимуться до межі свого закриття. Тому виникне потреба в прийнятті рішення про вибір перспективних джерел електроенергії. 3 урахуванням розвитку нової відновлюваної та чистої енергетики це можуть бути не атомні технології. Спорудження нових AEC i подальша їх експлуатація вимагають величезних витрат. Уже зараз зрозуміло, що ціна «атомної енергетики» 3 покриттям усіх витрат (від видобування урану до виведення AEC 3 експлуатації) $є$ надто високою. Які та коли будуть прийняті рішення, залежить від керівництва держави та громадськості. Проте наразі слід зосередитися на одному з головних питань - гарантування безпеки всієї наявної в Україні атомної галузі. Щоб цього досягти, потрібно в атомному комплексі України визначити небезпечні місця та правильно розставити пріоритети для реалізації проектів, орієнтованих на підвищення рівня безпеки. 


\section{СПИСОК ЛІТЕРАТУРИ}

1. Лисиченко Г., Штейнберг М., Чумак Д. та ін. Атомна індустрія України (Експертний огляд). - Норвегія, Осло: Bellona Foundation, 2017. - 122 с.

2. І. Шевченко. Російський ядерний зашморг: звільнитися раз і назавжди, березень, 2018 [Електронний ресурс] Режим доступу: https://dt.ua/energy_market/rosiyskiyyaderniy-zashmorg-zvilnitisya-raz-i-nazavzhdi-272280_.html.

3. Ядерная энергетика. Обращение с отработанным ядерным топливом и радиоактивными отходами. Обзор по материалам зарубежной и отечественной печати / Под ред. И.М. Неклюдова. - Киев: Наукова думка, 2006. - 253 с.

4. Перспективи розвитку уранової сировинної бази ядерної енергетики України / За ред. Г.В. Лисиченка, В.Г. Верховцева. - Київ: Наукова думка, 2014. - 355 с.

5. Бєгун В.В., Широков С.В., Бєгун С.В. та ін. Культура безпеки в ядерній енергетиці. - Київ, 2012. -539 с.

6. Закон України “Про об'єкти підвищеної небезпеки” від 18.01.2001 № 2245-III (Відомості Верховної Ради України, 2001, N 15, ст.73).

7. Методи оцінки ризику ISO/IEC 31010: 2009 - Міжнародний стандарт ISO / IEC 31010: 2009 «Менеджмент ризику» («Risk management - Risk assessment techniques»).

8. Керівництво ISO 73: 2009, Risk Ризик-менеджмент: Словник.

9. Додаток А до стандарту ISO 31000. Свойства улучшенного риск менеджмента. ISO 31000:2009 Международный Стандарт ISO 31000. Первое издание 2009-11-15. Риск Менеджмент - Принципы и руководства.

10.Концепція управління ризиками виникнення надзвичайних ситуацій техногенного та природного характеру. Схвалено розпорядженням Кабінету Міністрів України від 22 січня 2014 р. № 37-p.

11.Про затвердження плану заходів щодо реалізації Концепції управління ризиками виникнення надзвичайних ситуацій техногенного та природного характеру на 20152020 роки. Розпорядження Кабінету Міністрів України від 25 березня 2015 р. № 419-р.

12.Постанова КМУ "Про комплексні заходи, спрямовані на ефективну реалізацію державної політики у сфері захисту населення і територій від надзвичайних ситуацій техногенного та природного характеру, запобігання та оперативного реагування на них, на період до 2005 року” від 7 лютого 2001 р. N 122.

13.Закон України «Про поводження 3 відпрацьованим ядерним паливом щодо розміщення, проектування та будівництва централізованого сховища відпрацьованого ядерного палива реакторів типу ВВЕР вітчизняних атомних електростанцій» від 09.02.2012 № 4384-VI. Б.

14.Ядерна енергетика у світі та Україні: поточний стан та перспективи розвитку / За ред. К. Маркевич, В. Омельченко. - Київ: Центр Разумкова, 2015.

Стаття надійшла до редакиії 23.07.2018

\section{REFERENCES (TRANSLATED AND TRANSLITERATED)}

1. Lysychenko, G., Shtejnberg, M. \& Chumak, D. (2017). The Nuclear Industry in Ukraine - An overview. Norvegija, Oslo: Bellona Foundation.

2. Shevchenko, I. (2018, March). Rosijs'kyj jadernyj zashmorg: Zvil'nytysja raz i nazavzhdy. Retrieved from: https://dt.ua/energy market/rosiyskiy-yaderniy-zashmorgzvilnitisya-raz-i-nazavzhdi-272280.html (in Ukrainian).

3. Nekljudov, I. M. (Ed.). 2006). Jadernaja jenergetika. Obrashhenie s otrabotannym jadernym toplivom $i$ radioaktivnymi othodami. Obzor po materialam zarubezhnoj $i$ otechestvennoj pechati. Kyiv: Naukova dumka (in Ukrainian). 
4. Lysychenko, G., \& Verhovcev, V. (Eds.). (2014). Perspektyvy rozvytku uranovoi' syrovynnoi' bazy jadernoi' energetyky Ukrai'ny. Kyiv: Naukova dumka (in Ukrainian).

5. Bjegun, V. V., Shyrokov, S. V., \& Bjegun, S. V. (2012). Safety Culture in the Nuclear Power Industry. Kyiv (in Ukrainian).

6. Verkhovna Rada of Ukraine. (2001). Law of Ukraine "On Extremely Dangerous Objects" Kyiv: Vidomosti Verhovnoi' Rady Ukrai'ny (in Ukrainian).

7. Technical Committee ISO/TC 262. (2009). ISO 31010:2009 «Risk management - Risk assessment techniques».

8. Technical Committee ISO/TC 262. (2009). ISO Guide 73:2009 «Risk management Vocabulary»».

9. Technical Committee ISO/TC 262. (2009). ISO 31000:2009 «Risk Management Principles and Guidelines».

10. Cabinet of Ministers of Ukraine. Order (2014). "Pro shvalennja Koncepcii' upravlinnja ryzykamy vynyknennja nadzvychajnyh sytuacij tehnogennogo ta pryrodnogo harakteru". Kyiv: Oficijnyj visnyk Ukrai'ny (in Ukrainian).

11. Cabinet of Ministers of Ukraine. (2015). Order "Pro zatverdzhennja planu zahodiv shhodo realizacii' Koncepcii' upravlinnja ryzykamy vynyknennja nadzvychajnyh sytuacij tehnogennogo ta pryrodnogo harakteru na 2015-2020 roky". Kyiv: Oficijnyj visnyk Ukrai'ny (in Ukrainian).

12. Cabinet of Ministers of Ukraine. (2001). Resolution "Pro kompleksni zahody, sprjamovani na efektyvnu realizaciju derzhavnoi' polityky u sferi zahystu naselennja i terytorij vid nadzvychajnyh sytuacij tehnogennogo ta pryrodnogo harakteru, zapobigannja ta operatyvnogo reaguvannja na nyh, na period do 2005 roku". Kyiv: Oficijnyj visnyk Ukrai'ny (in Ukrainian).

13. Verkhovna Rada of Ukraine. (2012). Law of Ukraine "On Treatment of Depleted Nuclear Fuel in Respect of Siting, Designing and Constructing a Centralized Storage for Depleted Nuclear Fuel of WWER Type Reactors". Kyiv: Vidomosti Verhovnoi' Rady Ukrai'ny (in Ukrainian).

14. Markevych, K., \& Omel'chenko, V. (2015). Jaderna energetyka u sviti ta Ukrai'ni: potochnyj stan ta perspektyvy rozvytku. Kyiv: Centr Razumkova (in Ukrainian).

Text of the article was accepted by Editorial Team 23.07.2018

\section{Дрозд Іван Петрович}

доктор біологічних наук (екологія), старший науковий співробітник, провідний науковий співробітник відділу радіобіології та радіоекології Інституту ядерних досліджень НАН України

Адреса робоча: 03028 Україна, м. Київ, пр-т Науки, 47

Тел.: (097) 2698072 e-mail: idrozdnbu@ukr.net

ORCID ID 0000-0002-2965-9082 